\title{
Opsin Synthesis and mRNA Levels in Dystrophic Retinas Devoid of Outer Segments in Retinal Degeneration Slow (rds) Mice
}

\author{
Neeraj Agarwal, Izhak Nir, and David S. Papermaster \\ Department of Pathology, University of Texas Health Science Center at San Antonio, San Antonio, Texas 78284
}

\begin{abstract}
Opsin gene regulation, as a function of outer segment structure, was studied in normal and mutant retinal degeneration slow (rds) mice. We investigated the level of expression of the opsin gene in the rds mutant to determine if the reduced opsin content observed in this mutation (around $3 \%$ of normal) is a consequence of lowered expression of its gene. Normal BALB/C and rds mice were analyzed for levels of opsin mRNA and opsin content by Northern and immunoblot analysis, respectively. The rate of opsin synthesis in Isolated retinas was measured by ${ }^{35}$ S-methionine incorporation in vitro, followed by analysis of the radiolabeled opsin by SDSgel electrophoresis and autoradiography. Photoreceptor cell loss at various stages of degeneration was determined by quantitation of surviving photoreceptor nuclei. Opsin was localized in the mutant photoreceptors by immunoelectron microscopy of LR gold-embedded retinas using anti-opsin and antibody gold conjugates. The results indicate that 11and 30-d-old mutant mice have considerable levels of opsin mRNA (60-70\% of normal) and opsin synthetic rates (76$92 \%$ of normal), after the data from mutant mice are corrected for photoreceptor cell loss. We conclude, therefore, that the very low level of opsin observed in rds mice $(\sim 3 \%)$ is not a result of greatly reduced expression of the opsin gene. Rather, continuous turnover of newly synthesized opsin as a result of its failure to become sequestered into an intact outer segment appears to account for the low levels of opsin in the rds mutant.
\end{abstract}

Retinal photoreceptors are highly specialized neuronal cells. Their structure is a consequence of a carefully orchestrated balance of degradative and synthetic events acting on different domains of the cell. The photosensitive rod's outer segment consists of a stack of disk-shaped membranes enveloped by a plasma membrane. The adjacent inner segment contains an abundance of mitochondria and apparatus for protein synthesis and transport. The remainder of the cell contains the nucleus, axon, and synaptic terminal. The photopigment opsin is synthesized in the inner segment and delivered to the outer segment, possibly along the plasma membrane of the connecting cilium (Papermaster et al., 1985; Besharse, 1986). In normal retinas, outer segment

\footnotetext{
Received Jan. 25, 1990; revised Apr. 27, 1990; accepted May 23, 1990.

This work was supported in part by NIH Grant EY-6892. Our thanks are extended to Nancy Ransom for excellent technical assistance, to Drs. C. Alex McMahan, J. Metter, and Barbara Schneider for helpful discussions of mRNA quantitation, and to Tammy Lowe for preparing the manuscript.

Correspondence should be addressed to Dr. Neeraj Agarwal, Department of Pathology, University of Texas Health Science Center, San Antonio, TX 782847750.

Copyright $\odot 1990$ Society for Neuroscience $0270-6474 / 90 / 103275-11 \$ 03.00 / 0$
}

disks, composed largely of opsin (Hall et al., 1969), are replaced by shedding of old disk membranes at the tip while new disks are added at the base of the outer segment (Young, 1985). The 2 cellular processes, disk shedding and addition, are balanced and under circadian control so that the outer segment length is conserved except under conditions of extreme light exposure or deprivation (Besharse, 1986). Studies of opsin gene expression have demonstrated variation in levels of opsin mRNA during the daily light cycle (Bowes et al., 1988; Korenbrot and Fernald, 1989). These findings suggested there was a close coupling of outer segment length, light capture, and opsin synthesis.

We have used a mutant mouse bearing the $r d s$ (retinal degeneration slow) gene in order to gain insight into opsin gene regulation in the absence of outer segment formation. Normally, mice form outer segments by postnatal day 7 (P7) (Caravaggio and Bonting, 1963). Photoreceptor cells of mice with the rds mutation differentiate normally for the first few postnatal days. The photorcceptor inner segments project an extended cilium, but during the next few days of postnatal life, outer segments fail to form, and only rudimentary disks and opsin-laden vesicles become assembled at the tip of the connecting cilium. Rods then begin to die slowly, so that a considerable loss of photoreceptor nuclei in the $r d s$ mice is evident by the third postnatal week. The photoreceptor cell death is gradual and is completed only in 1-year-old mice (Sanyal and Hawkins, 1986).

The autosomal recessive $r d s$ gene has been mapped to mouse chromosome 17 (van Nie et al., 1978), and its cDNA was recently sequenced (Travis et al., 1989). The gene codes a sequence of a protein that has a molecular mass of $39,259 \mathrm{Da}$. The predicted protein appears to be peripherin; it is expressed only in photoreceptors at the margins of disks (Connell et al., 1990). The mutant $r d s$ gene's putative amino acid sequence, if translated, contains a transposition, possibly of a mouse oncogene, that interrupts the normal sequence and generates a shortened sequence lacking the $\mathrm{C}$-terminal 87 amino acid residues of the normal counterpart (Travis et al., 1989).

Although outer segments are absent, limited light responses can be observed in the rds mice (Cohen, 1983; Reuter and Sanyal, 1984). These responses may be a consequence of residual opsin that was detected by immunocytochemistry in the plasma membrane that encloses the inner segment, nucleus, and synaptic terminal (Nir and Papermaster, 1986; Jansen et al., 1987; Usukura and Bok, 1987). The molecular and physiological events currently described do not yet account for the failure to form outer segments or for the cell death of photoreceptors.

We wished to explore the consequences of the $r d s$ mutation on levels of opsin gene expression because immunoassays reveal that the steady-state content of opsin in the rds retina is very low, about 3\% of normal (Schalken et al., 1985). Opsin's gene 
Table 1. Opsin mRNA levels in rds retinas compared to BALB/c controls

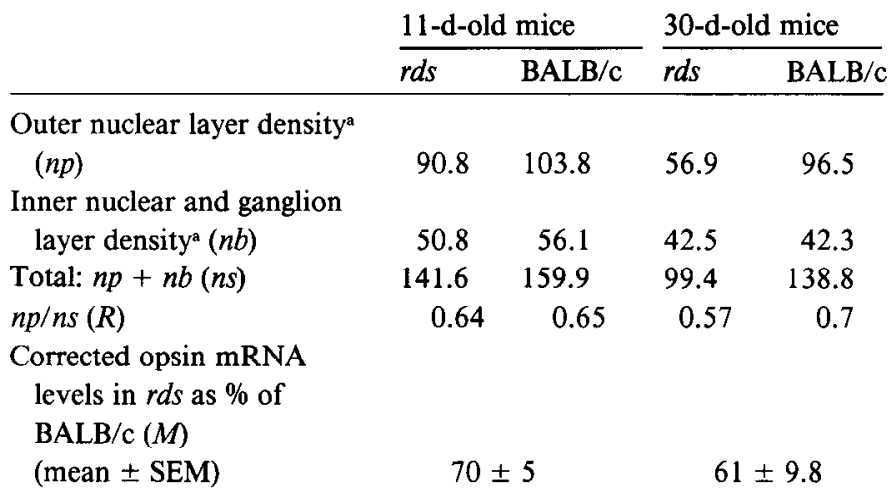

Opsin mRNA levels in each age group of $r d s$ mice were calculated by Equation (1) (see Materials and Methods).

${ }^{a}$ Nuclear density $=$ number of nuclei per $50-\mu \mathrm{m}$ length of retina.

lies on chromosome 6 in the mouse (D. Farber, unpublished observations). If the reduction in opsin content were a direct trans effect of the $r d s$ gene on opsin gene expression, its effect might be detected either at the level of opsin gene transcription or upon translation of its mRNA.

In the present study, we discovered that the low levels of opsin in the rds mutant are not a result of a major reduction in opsin gene expression in these mutant photoreceptors. Rather, the opsin mRNA levels and the rates of opsin synthesis in the $r d s$ retina and normal retinas are slightly reduced when the observed data are corrected for cell loss. Phagocytosis of newly synthesized opsin-laden membranes is observed at earlier times than normal and continues in older mice so that the only opsin detectable in the retina is either distributed on the rod cell's plasma membrane or in small amounts in the interphotoreceptor space.

\section{Materials and Methods}

Animals. BALB/c mice were obtained from Jackson Laboratories (Bar Harbor, ME). Mutant 020/A rds/rds mice were obtained from Dr. Janet Blanks (USC, Los Angeles) from a colony of Dr. Sanyal's (Netherlands) and were bred locally. The animals were maintained under a 12-hr/12$\mathrm{hr}$ dark/light cycle and were exposed to low (3-5 foot-candles) light levels. The handling of the mice were in accordance with the ARVO resolution on the use of animals in research and with NIH and AAALAC guidelines. Mice at various ages were killed 1-2 hr after the onset of light by exposure to $\mathrm{CO}_{2}$.

Postembedding immunocytochemical procedures. Intact posterior eye cups were fixed in $1 \%$ glutaraldehyde in $0.15 \mathrm{~m}$ phosphate buffer $(\mathrm{pH}$, 7.0 ) or $1 \%$ glutaraldehyde and $2 \%$ formaldehyde in $0.1 \mathrm{M}$ phosphate buffer. The tissue strips were dehydrated in a graded ethanol series and embedded in LR Gold (Polysciences) as described by Nir et al. (1989). All the steps were conducted at $4^{\circ} \mathrm{C}$. Thin sections of the retina were cut at different regions along the central-to-peripheral axis. For detection of opsin, 2 antibodies were used: (1) affinity-purified sheep anti-bovine opsin (Papermaster et al., 1978), a polyclonal antibody largely directed against the $\mathrm{N}$-terminus of bovine opsin (Hargrave et al., 1986) and (2) the monoclonal antibody (mAb) 1D4, directed against the C-terminus of bovine opsin (MacKenzie et al., 1984), kindly provided by Dr. Robert Molday (UBC, Vancouver, BC, Canada). LR gold-embedded thin sections were exposed sequentially to sheep anti-opsin at $25 \mu \mathrm{g} / \mathrm{ml}$ or mAb $1 D 4$ at $100 \mu \mathrm{g} / \mathrm{ml}$, followed by rabbit anti-sheep IgG $(100 \mu \mathrm{g} /$ $\mathrm{ml})$ or rabbit anti-mousc IgG $(100 \mu \mathrm{g} / \mathrm{ml})$, respcctively. Bound antibodies were detected by goat anti-rabbit IgG-10 nm gold (Janssen) diluted $1: 10$ with $1 \% \mathrm{BSA}$ in $0.1 \mathrm{~m}$ Tris- $\mathrm{HCl}$ buffer (Schneider and Papermaster, 1983). After drying, the sections were stained with uranyl acetate and lead citrate before electron microscopy.
Quantitation of photoreceptor cell nuclei. Enucleated intacteyes were fixed overnight with $1 \%$ glutaraldehyde and $2 \%$ formaldehyde in $0.1 \mathrm{M}$ phosphate buffer at $4^{\circ} \mathrm{C}$. The eyes were then bisected into 2 hemispheres through the optic nerve and postfixed with $1 \% \mathrm{OsO}_{4}$ in $0.15 \mathrm{M}$ phosphate buffer $(\mathrm{pH}, 7.0)$. One hemisphere from each eye was oriented and embedded in epoxy resins as described by LaVail and Battelle (1975). The embedded blocks were sectioned so as to include the full length of the retina from the optic nerve head to the far periphery. Thick sections $(2 \mu \mathrm{m})$ were stained with Toluidine blue and were viewed at a magnification of $1000 \times$. Photoreceptor nuclei were counted along $50-\mu \mathrm{m}$ segments of the retina with the aid of an ocular micrometer, and data are expressed as number of nuclei per $50 \mu \mathrm{m}$ of retinal length. Measurements started $100 \mu \mathrm{m}$ from the optic nerve head and continued at $100-\mu \mathrm{m}-150-\mu \mathrm{m}$ intervals to the far periphery. The results were expressed as number of nuclei per $50 \mu \mathrm{m}$ length of retina. At each age, 34 eyes from different mice of separate litters were analyzed. The number of nuclei in the far periphery (about $200-300 \mu \mathrm{m}$ from the ora serrata) was reduced. However, because the far periphery was dissected out during isolation of the retina for RNA isolation and incorporation studies, the values for nuclear density in the far periphery were not included in calculating the mean nuclear density.

$c D N A$ probes. A 1.64-kilobase $(\mathrm{Kb})$ bovine opsin cDNA probe, a gift of Dr. Jeremy Nathans (Johns Hopkins, Baltimore), was purified from the flanking pBR322 plasmid sequences by EcoRI (BRL) digestion. Similarly, a 4-Kb rat cytoplasmic $\beta$-actin genomic DNA fragment, a gift of Dr. Z. D. Sharp (UT Health Science Center, San Antonio; originally cloned by Dr. U. Nudel of the Weizman Institute, Rehovot, Israel), was purified from the pBR322 vector sequences by double digestion with restriction enzymes EcoRI and Hind III (BRL). The opsin and $\beta$-actin inserts were purified by separating the digested DNA on a $1 \%$ agarose gel and trapping the DNA insert by DEAE paper ( $\mathrm{S} \& \mathrm{~S}$, Inc.) as described by Maniatis et al. (1982).

Northern blot analysis. Total RNA from BALB/c and $r d s$ retinas and liver, frozen in liquid $\mathrm{N}_{2}$ and stored at $-70^{\circ} \mathrm{C}$, was isolated by extraction in guanidinium isothiocyanate and centrifugation through a $\mathrm{CsCl}$ gradient as described by Chirgwin et al. (1979). Purified total retinal RNA was separated by electrophoresis in $1.1 \%$ agarose-formaldehyde denaturing gels as described by Lehrach et al. (1977) and blotted to a nytran nylon membrane (S \& S, Inc.) for a period of $24 \mathrm{hr}$ in $20 \times$ SSC. Following the blotting, the nylon membrane was baked at $80^{\circ} \mathrm{C}$ for a period of $2 \mathrm{hr}$ under vacuum. The blot was then subjected to hybridization with ${ }^{32} \mathrm{P}$-oligolabeled opsin cDNA or $\beta$-actin genomic DNA probes using the procedure described by Maniatis et al. (1982). After hybridization, the blot was subjected to a stringent wash procedure. For opsin transcripts, the blot was first washed with $2 \times$ SSC with $0.1 \%$ SDS at room temperature for a period of $30 \mathrm{~min}$. The blot was further washed in $0.1 \times \mathrm{SSC}$ with $0.1 \% \mathrm{SDS}$ at $65^{\circ} \mathrm{C}$ for a period of $2 \mathrm{hr}$ with shaking. For $\beta$-actin, after washing at room temperature in $2 \times$ SSC with $0.1 \%$ SDS for $30 \mathrm{~min}$, the blot was washed in $0.2 \times$ SSC with $0.1 \%$ SDS at $50^{\circ} \mathrm{C}$ for a period of $1 \mathrm{hr}$. Afterwards, the blots were subjected to autoradiography using Kodak X-Omat $\mathrm{x}$-ray film at $-70^{\circ} \mathrm{C}$ with an intensifying screen.

The density of each of the 5 opsin mRNA transcripts and of actin mRNA was determined by use of IMAGE, an image-processing and analysis computer program for the Macintosh II computer developed by Wayne Rasband at NIH (freely available on many bulletin boards and user-group libraries). Images were captured according to the program directions with a Philips 56473 digital $C C D$ camera connected via a QuickCapture 2255 (Data Translation) frame-capture board (O'Niel et al., 1989). We first established the linearity of densitometry by comparing the observed density of a Kodak optical density wedge with the published densities from the manufacturer using procedures developed by Drs. Gary Griess and Philip Serwer (unpublished observation). A correlation coefficient of 0.99 was obtained in a gray scale range of 31245 . We next compared the density of a $\beta$-actin mRNA Northern blot autoradiograph loaded successively with samples from 2 to $20 \mu \mathrm{g}$ RNA and exposed for several time periods after blotting with ${ }^{32} \mathrm{P}$-labeled $\beta$-actin genomic DNA probes $\left(2-4 \times 10^{9} \mathrm{cpm} / \mu \mathrm{g}\right.$ DNA $)$. The correlation coefficient of density to the amount loaded in each lane again was found to vary from 0.97 to 0.99 with several repeated analyses. We also compared results obtained using IMAGE with those obtained using a laser densitometer (LKB Instruments) and results of densities determined by more than one of us scanning the same autoradiographs; we arrived at essentially equal relative values (range, $\pm 3 \%$ ). Satisfied with the linear performance of the program and image-capture system and the repro- 


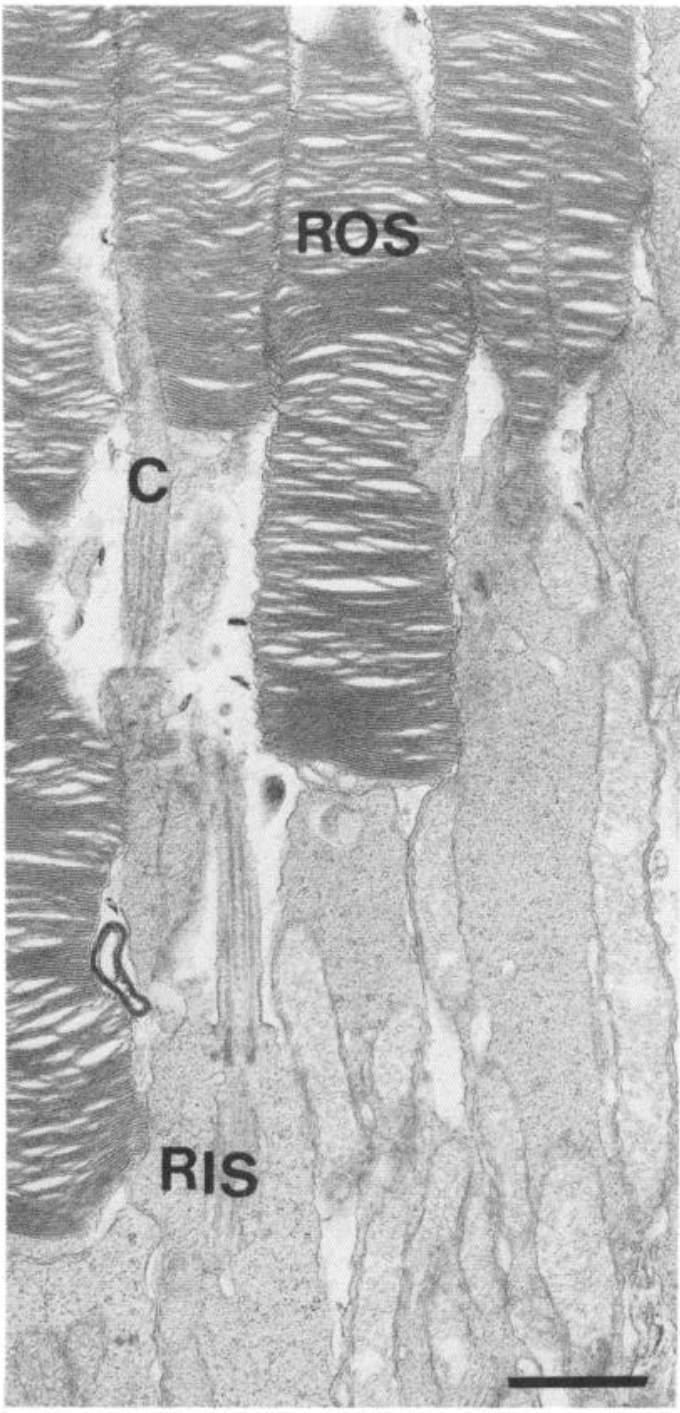

A

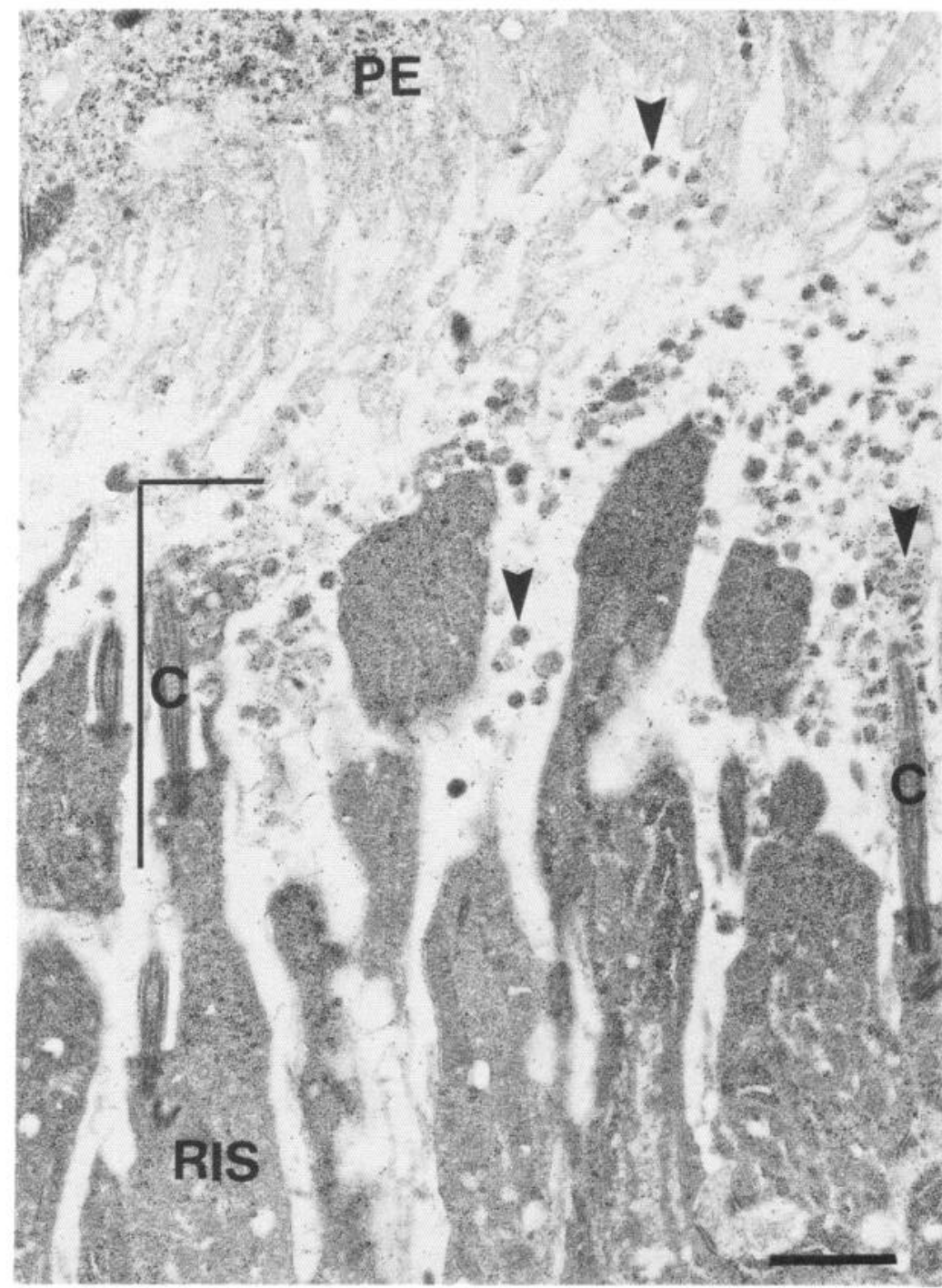

B

Figure 1. A, Normal 30-d-old BALB/c retina (embedded in epon). Rod inner segments $(R I S)$ and outer segments $(R O S)$ are joined by connecting cilia $(C)$. Magnification $14,250 \times$. Scale bar, $1.0 \mu \mathrm{m}$. B, Mutant $r d s$ retina, $40 \mathrm{~d}$ old (embedded in LR Gold). Rod inner segments $(R I S)$ with projecting cilia $(C)$ are seen. Outer segments are absent. Numerous small vesicles (arrowheads) are present at the tip of the cilium, in the subretinal space between the photoreceptors and the pigment epithelium microvilli $(P E)$. A portion of one cell (outlined) is enlarged in Figure 2. Scale bar, $1.0 \mu \mathrm{m}$.

ducibility of the analysis, we evaluated the opsin and $\beta$-actin mRNA band densities of 7 separate experiments at 30 days of age and 3 experiments of 11 days of age.

The loss of photoreceptor cells impacts on the quantitative analysis of mRNA levels and of synthesis of proteins that are the exclusive products of rod cells. We therefore used the data obtained from the quantitation of photoreceptor cell loss to correct the observed values for opsin mRNA and opsin synthesis. Moreover, corrections for loading variation in each lane of the gels were needed. Each lane was loaded with nearly equal amounts of RNA (5 $\mu \mathrm{g})$, which, accordingly, added a greater number of retina equivalents as the $r d s$ mice aged. The absolute amounts of RNA loaded, however, are not relevant for this analysis, except for presentation of the results visually by autoradiography, because we correct our observed values of opsin mRNA density for variation of mRNA loading by comparing the relative actin mRNA content of a lane from the $r d s$ mouse retinas with a lane from BALB/c controls, then correcting for cell loss. Our calculations were based on 2 assumptions that are widely adopted in this sort of analysis but are difficult to prove: (1) each cell in the retina contributes equal amounts of actin
mRNA, and (2) the actin mRNA content of the $r d s$ photoreceptors is constant at all ages until the cells die. Our calculations determine the opsin mRNA level in $r d s$ as percentage of $\mathrm{BALB} / \mathrm{c}$ at the same age by the equation:

$$
\begin{aligned}
M & =\% r d s / \mathrm{BALB} / \mathrm{c} \\
& =100 \times O_{r d s} / O_{\mathrm{BALB} / c} \times A_{\mathrm{BALB} / c} / A_{r d s} \times R_{\mathrm{BALB} / c} / R_{r d s},
\end{aligned}
$$

where $O$ is the measured opsin mRNA band density, $A$ is the measured actin mRNA band density as determined by Northern blot analysis, and $R$ is a proportionality factor derived from the number of cells in each retinal layer: $R=n p / n s$, where $n p=$ outer nuclear layer (ONL) cell density and $n s=$ the sum of the cell densities in the ONL, inner nuclear layers (INL), and ganglion cell layers. The equation is general, however, and can be used to compare one age group of $r d s$ mice with another or one age group of $r d s$ mice with BALB/c mice of another age group. If subsequent research should demonstrate that the assumptions are quantitatively incorrect, that is, if it is found that the actin mRNA content of various retinal cells varies or that the actin mRNA content of rods varies with age, our results can be readily reevaluated by intro- 


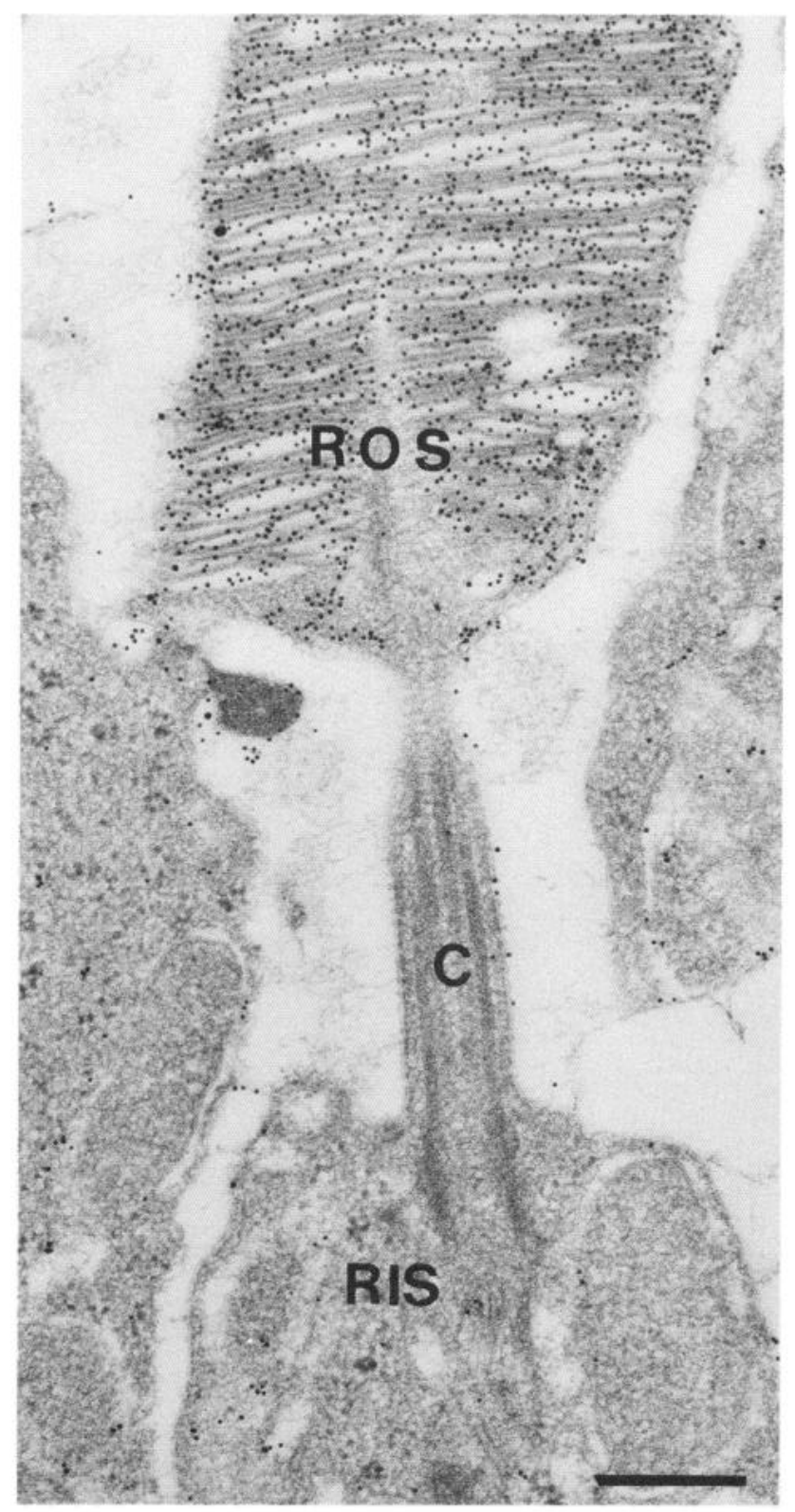

A

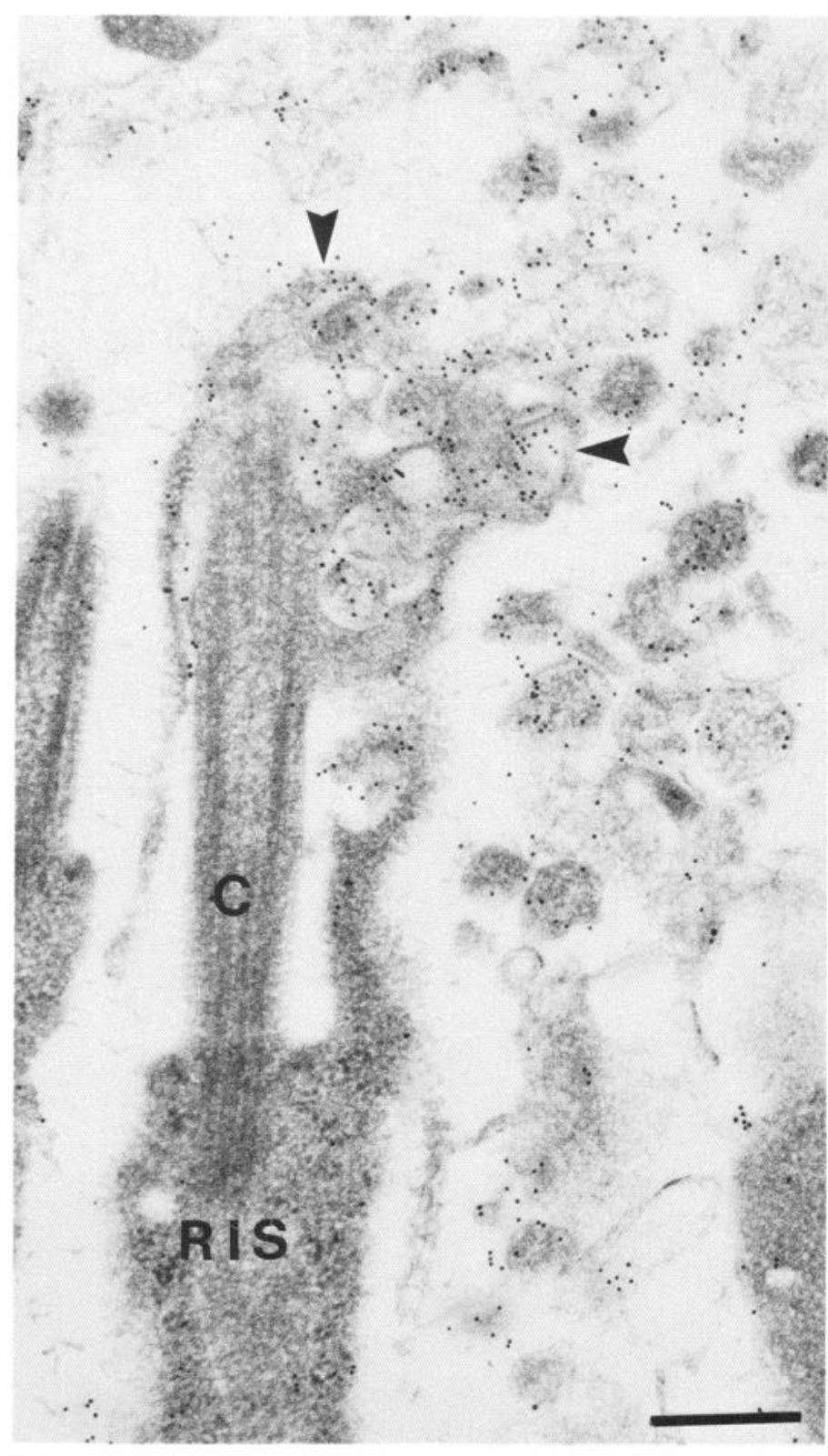

B

Figure 2. Opsin localization in BALB/c and rds retinas (embedded in LR Gold) by postembedding labeling with sheep anti-opsin, followed by rabbit anti-sheep IgG and goat anti-rabbit IgG-10 nm gold. $A$, Normal retina. High labeling density is seen in the outer segment, associated with the disk membrane. $B$, Mutant retina (higher magnification of the cell outlined in Figure $1 B$ ). Opsin is localized in the vesicular membranes that accumulate in the subretinal space. These opsin-containing vesicles appear to bud from the distal ciliary tip (arrowheads). Scale bars, $0.3 \mu \mathrm{m}$. RIS, rod inner segments; ROS, rod outer segments.

duction of the relative proportional changes in actin mRNA content into the equation. The results of these calculations are presented in Table 1. Details on the derivation of the equation are available from the authors upon request.

In Vitro protein synthesis. In 3 separate experiments, 6-8 retinas were incubated in RPMI 1640 methionine-free medium (Flow Labs), buffered with $30 \mathrm{~mm}$ Hepes-Tris ( $\mathrm{pH}, 7.4$ ) with $10 \mu \mathrm{Ci} / \mathrm{ml}^{35} \mathrm{~S}$-methionine (NEN) for a period of $2 \mathrm{hr}$ at $37^{\circ} \mathrm{C}$ with a flow of gas $\left(5 \% \mathrm{CO}_{2}\right.$ and $\left.95 \% \mathrm{O}_{2}\right)$ and gentle shaking following the method of St. Jules and O'Brien (1986). After the incubation, the retinas were quickly washed and homogenized in the presence of a mixture of protease inhibitors at a final concentration of $10 \mu \mathrm{g} / \mathrm{ml}$ antipain, $2 \mathrm{~mm}$ leupeptin, and $10 \mathrm{kU}$ aprotinin as described previously (Nir et al., 1989). The retinal homogenate was solubilized (in Bromophenol blue containing $5 \%$ SDS, $1.5 \% \beta$-mercaptoethanol, and $2 \%$ glycerol) and electrophoresed on a $10 \%$ SDS polyacrylamide gel to separate the retinal proteins. After electrophoresis, the gel was stained with Coomassie blue and treated with $1 \mathrm{M}$ sodium salicylate before it was dried under vacuum. The dried gel was subjected to autoradiography using a Kodak X-Omat $\mathrm{x}$-ray film at $-70^{\circ} \mathrm{C}$ with an intensifying screen.

Each lane in the gel was loaded with equal numbers of retina equivalents. Because of photoreceptor loss, the $r d s$ lanes were loaded with products of reduced numbers of photoreceptors. In order to correct the observed amount of newly synthesized opsin for rod cell loss, the value 


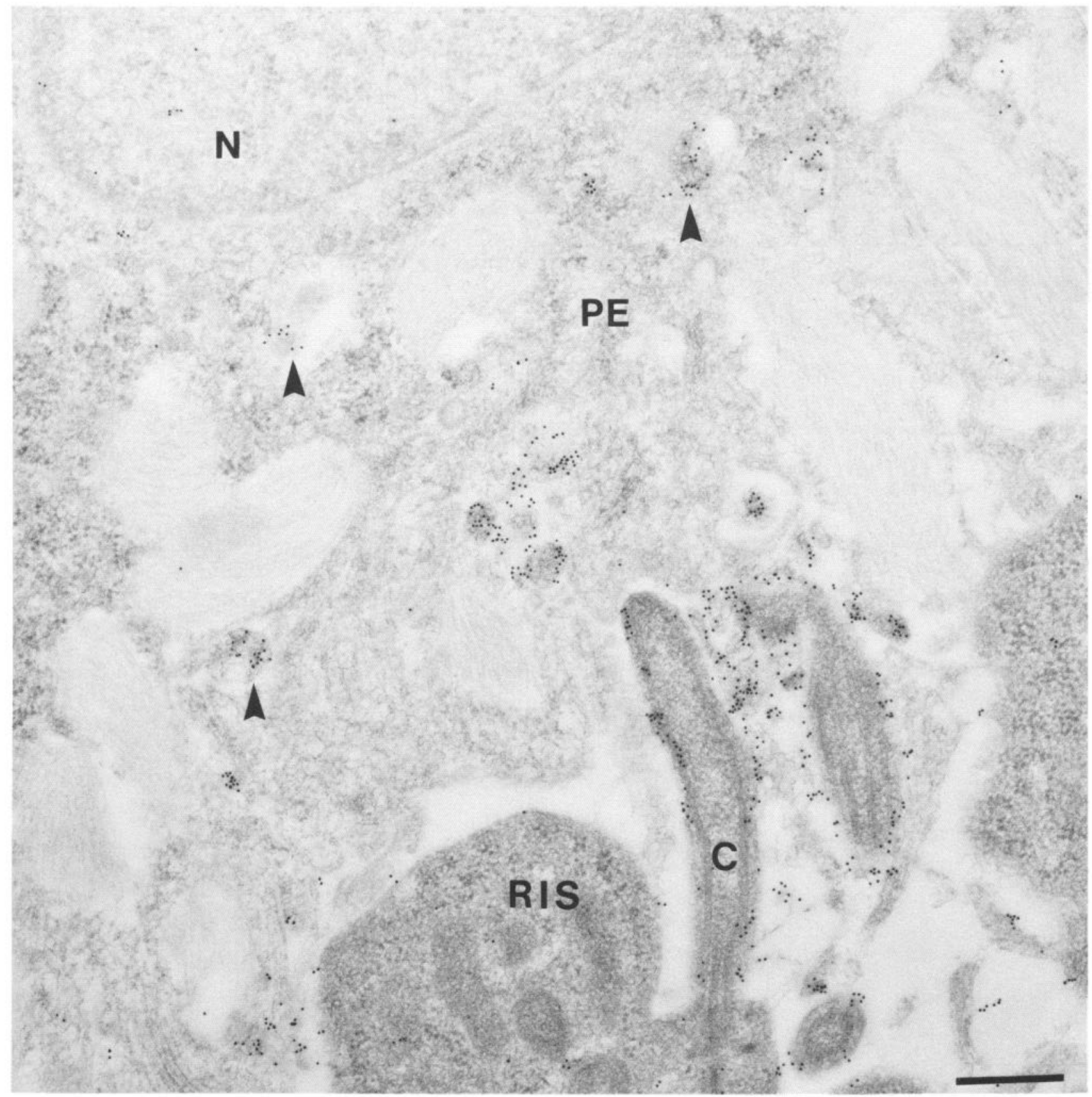

Figure 3. Opsin in pigment epithelium of 7-d-old mutant rds mouse (embedded in LR Gold). Postembedding labeling with sheep anti-opsin is as described in Figure 2. Phagocytosis of opsin-containing structures is already evident at this young age by the labeling of small phagosomes with the anti-opsin antibody (arrowheads). Scale bar, $0.3 \mu \mathrm{m}$. RIS, rod inner segment; PE, pigment epithelium; C, cilium; N, nucleus.

of the band density in the autoradiograph was multiplied by the ratio of photoreceptor nuclei in $r d s$ retinas to photoreceptor nuclei in BALB/c retinas of the same age.

Immunoblotting. Immunoblotting was conducted by a modification of the procedure of Towbin et al. (1979) as described by Deretic and Hamm (1987). The binding of mAb 1D4 and the immunoperoxidase reaction was used to estimate the opsin content of retinas of the mutant and normal mice at 28 days. As the detection system was enzymatic, greatly diluted samples of retinas were loaded in each lane. The samples of lanes 1 and 2 were from 28 -d-old BALB/c and $r d s$ mice, respectively, and contained 0.000175 retinas for BALB/c and 0.0022 retinas for $r d s$ mice. A typical immunoblot was subjected to densitometric scanning using IMAGE, as described in Materials and Methods for Northern blot analysis. The band density obtained for both the BALB/c and $r d s$ mice was converted to the density per single retina before calculating the percent of opsin levels of $r d s$ retinas as compared to the BALB/c controls.

\section{Results}

Immunocytochemistry and quantitation of photoreceptor cell loss

Photoreceptors of $r d s$ mice differ markedly from normal controls. The structural features of the mutant $r d s$ and normal BALB/c photoreceptors are compared in Figure 1, $A$ and $B$. The absence of the outer segment layer is the distinguishing feature 


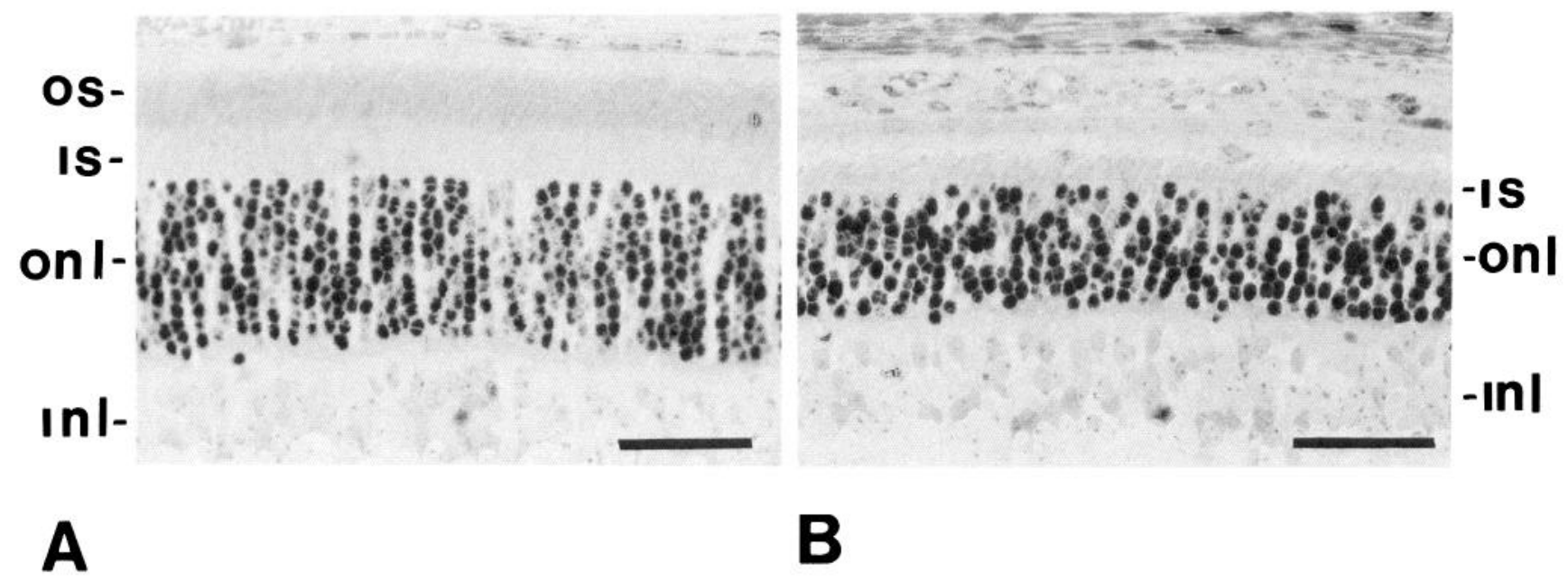

Figure 4. Photoreceptor nuclear layer in 28-day-old mice. A, normal retina. B, Mutant $r d s$ retina. The reduction in thickness of the onl, containing photoreceptor nuclei, is due to photoreceptor cell death in the mutant. In contrast, younger, 11-d-old mice have only a slight (12.5\%) reduction in the onl nuclear density. In the 28-d-old $r d s$ retina, the reduction in onl thickness is due to a $41 \%$ loss in photoreceptor nuclei (see Table 1 ). INL, inner nuclear layer; IS, inner segments; OS, outer segments. Scale bars, $50 \mu \mathrm{m}$.

of the $r d s$ mutation. In the normal retina, disks are formed by the evagination of the plasma membrane at the base of the outer segment, and the disks and the outer segment plasma membrane contain most of the opsin detected by immunoelectron microscopy (Fig. $2 A$ ). By contrast, opsin-laden vesicular membrane profiles appeared to bud from the distal ciliary tip and accumulate in the interphotoreceptor space in the $r d s$ retina (Fig. $2 B$ ). This result appears to represent an abortive attempt to form disk membranes.
Opsin-laden vesicles in the interphotoreceptor space are phagocytosed by the adjoining pigment epithelium; small phagosomes in the pigment epithelium are labeled by anti-opsin (Fig. 3). Phagocytosis of opsin-laden membranes was observed as early as P7. It parallels the onset of opsin delivery to the subretinal space.

Death of photoreceptors during the first year is a characteristic feature of the $r d s$ mutation, which should be considered in a comparison of the biosynthetic capacity of the mutant and nor-
$5.2 \mathrm{~Kb}-$

$3.6 \mathrm{~Kb}-$

$3.2 \mathrm{~Kb}-$

$2.6 \mathrm{~Kb}-$ $2.0 \mathrm{~Kb}-$

Figure 5. Northern blot analysis of total retinal RNA from 11 - and 30 -d-old $r d s$ and $\mathrm{BALB} / \mathrm{c}$ mice. Total retinal RNA (5 $\mu \mathrm{g} /$ lane) was electrophoresed through a formaldehyde-agarose gel, blotted on nytran membrane, and probed with a ${ }^{32} \mathrm{P}$-oligolabeled bovine opsin cDNA. Mouse liver (5 $\mu \mathrm{g})$ and bovine retinal $(0.5 \mu \mathrm{g})$ RNA were used as controls. The $\beta$-actin served as an internal control for the loading of total RNA in each lane.

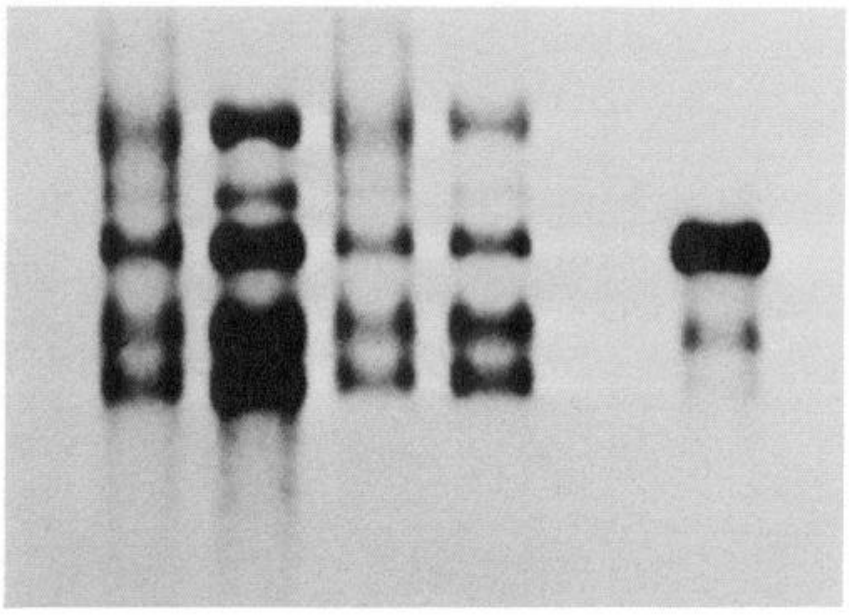




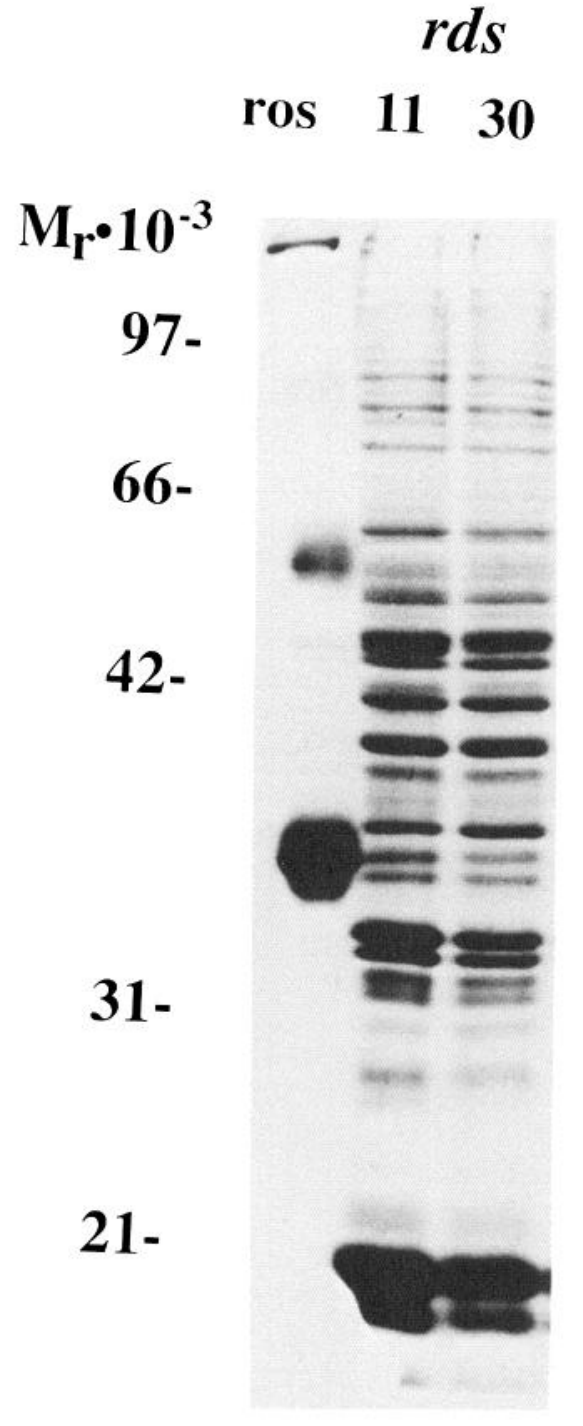

BALB/c

1130 


\section{$\mathrm{BALB} / \mathrm{C} \quad r d s$}

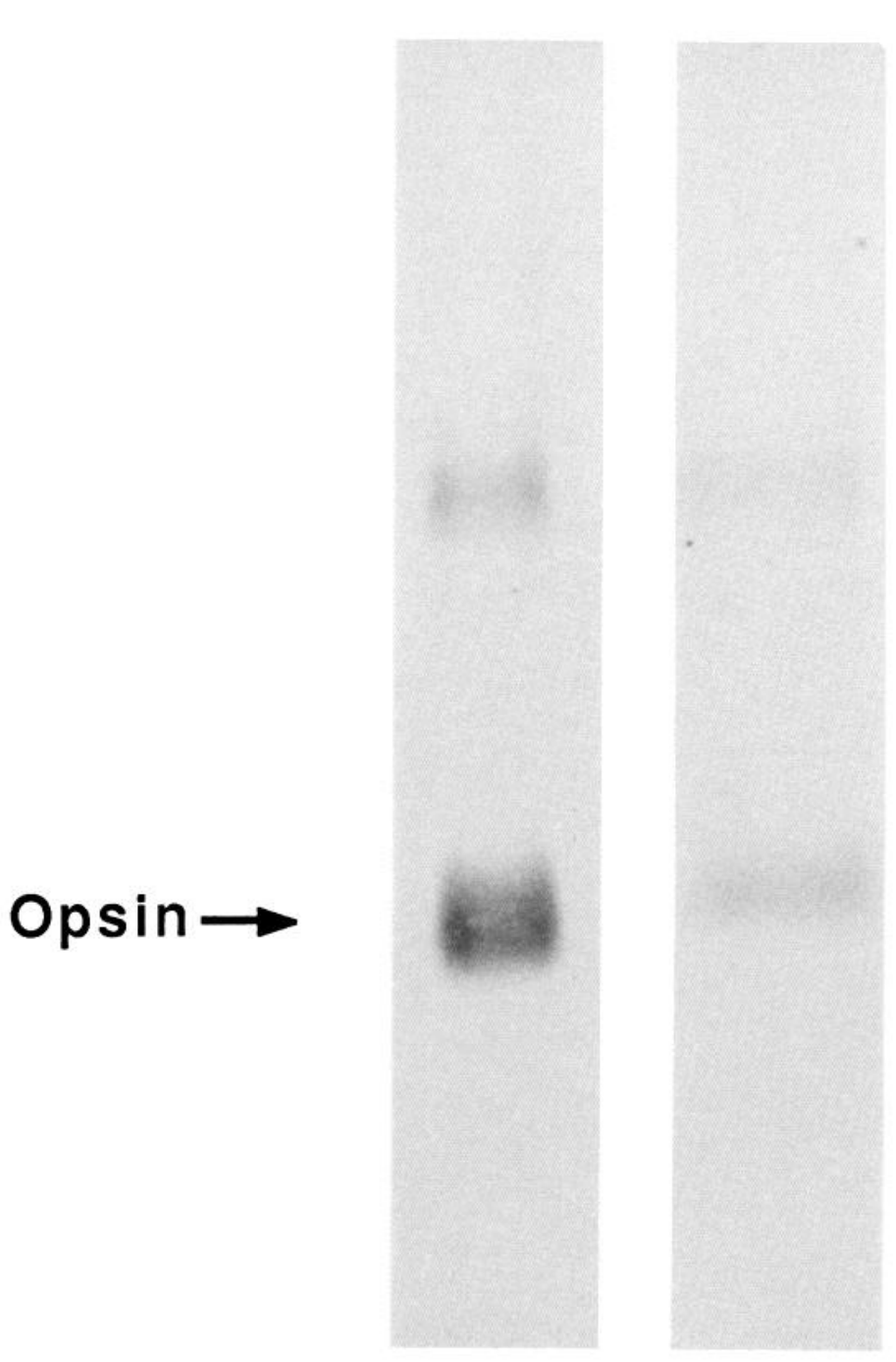

Figure 7. Immunoblot analysis of retinal proteins of $r d s$ and BALB/c mice. A gel was electrophoretically blotted into a PVDF Immobilon P membrane ( $0.45 \mu \mathrm{m}$; Millipore), and opsin was detected with anti-opsin $\mathrm{mAb}$ 1D4 and peroxidase-conjugated goat anti-mouse IgG (Kirkegaard and Perry Laboratories, Inc., Gaithersburg, MD). The opsin band is shown by the arrow. The $r d s$ mouse retina contains greatly reduced levels of opsin.

The autoradiographs of gels probed with radiolabeled opsin cDNA or with $\beta$-actin cDNA were subjected to densitometric scanning to estimate the amount of opsin mRNA and corrected for variation in loading by dividing by the actin mRNA density and the relative photoreceptor cell loss. After correction for cell loss with increasing age, the calculated level of opsin mRNA in 11- and 30-d-old $r d s$ retinas was reduced to about $60-70 \%$ of the levels in normal retinas (Table 1).

\section{Rates of opsin biosynthesis in retinas of $\mathrm{rds}$ and $B A L B / c$ mice}

We evaluated the efficiency of opsin mRNA translation by determining the amount of newly synthesized opsin during $2 \mathrm{hr}$

\begin{tabular}{lcc}
\hline $\begin{array}{l}\text { Table 2. Opsin synthesis by } r d s \\
\text { controls }\end{array}$ & mouse retinas compared to BALB/c \\
& 11-d-old mice & $\begin{array}{l}\text { 30-d-old } \\
\text { mice }\end{array}$ \\
\hline$n p_{r d s} / n p_{\text {BALB } / c^{a}}(N)$ & 0.82 & 0.59 \\
$\begin{array}{l}\text { Corrected opsin synthesis by } r d s \\
\text { mouse retinas as } \% \text { of BALB } / \mathrm{c}\end{array}$ & & \\
$\begin{array}{l}\text { controls }(C) \text { (mean } \pm \mathrm{SEM}) \\
\text { (m) }\end{array}$ & $76 \pm 5.26$ & $92 \pm 3.0$
\end{tabular}

Opsin synthesis in each age group was calculated by the equation $C=S_{\text {did }}$ $\left(S_{\mathrm{BALB} / \mathrm{c}} \times N\right) \times 100$, where $S$ is the opsin band density measured in the SDS gel autoradiogram.

"See Table 1 for definition and values of $n p$.

of in vitro incorporation of ${ }^{35} \mathrm{~S}$-methionine into protein in isolated $r d s$ and BALB/c retinas. Duplicate SDS gels of homogenized retinas were stained with Coomassie blue or immunoblotted with anti-opsin mAb 1D4. In the stained gel (Fig. 6), purified frog rod outer segments were included as a marker for opsin. An opsin band is visible at $35 \mathrm{kDa}$ in both $r d s$ and BALB/c retinas. As expected, the stained density of the opsin band is greatly reduced in $r d s$ mice. The mean of the 2 separate experiments showed that the steady-state level of opsin in the mutant retina was $2.69 \pm 0.23$ compared to the control BALB/c mice (Fig. 7), which is comparable to the reductions described in the earlier studies by Jansen et al. (1987) and Usukura and Bok (1987). The stained gel was autoradiographed to reveal that newly synthesized opsin is present at high levels in these young $r d s$ retinas (Fig. 8). These autoradiographs were subjected to densitometric scanning. When corrected for the cell loss in $r d s$ retinas, the results of scanning show that the photoreceptors in the young $r d s$ retina maintain a considerable capacity to synthesize opsin at levels of $76-92 \%$ of that measured in normal retinas (Table 2).

\section{Discussion}

Variation in opsin gene expression in the normal retina has been observed both during rod cell development and during dark/ light cycles in mature rods. In toad and fish retinas, opsin mRNA levels peak during the light phase and are reduced considerably in the dark (Korenbrot and Fernald, 1989). In the mouse retina, opsin mRNA levels increase prior to the onset of light, but variation from the maximal levels is much smaller than in lower vertebrates (Bowes et al., 1988).

In the amphibian retina, in addition to circadian variation of opsin gene transcription, there is evidence of variation in opsin synthesis that may parallel but lag temporally behind increases and decreases in opsin mRNA (Matsumoto and Bok, 1984; Bird et al., 1988). Diurnal variations in rod outer segment disk addition were studied by analysis of the number of newly assembled open disks at the base of the rod outer segment at different time periods in the light/dark cycle (Besharse et al., 1977). This analysis revealed a burst of disk assembly in the morning. Similar studies in the mice did not reveal a major difference in the number of open (new) disks, though the possibility of small daily variation in the rate of disk assembly could not be ruled out (LaVail, 1973). In the rat retina, analysis of opsin synthesis did not reveal rhythmic changes during the dark/light phases. 


\section{$r d s$}

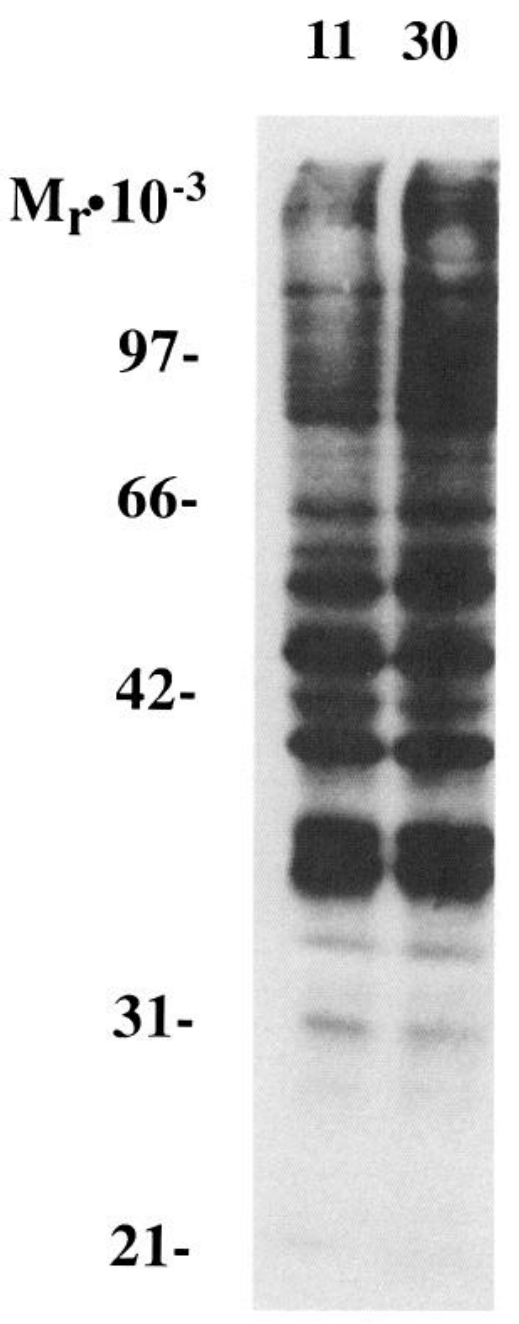

\section{BALB/c}

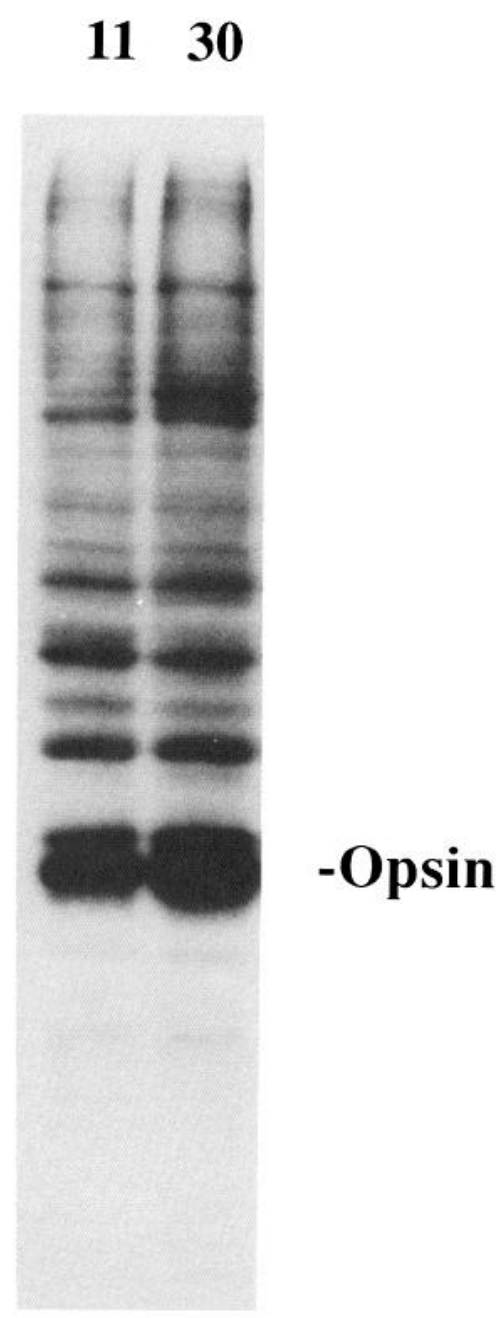

Figure 8. Incorporation of ${ }^{35} \mathrm{~S}-\mathrm{methi}-$ onine into newly synthesized opsin in 11 - and 30 -d-old $r d s$ and BALB/c mice. The Coomassie blue stained and dried gel was subjected to autoradiography. The ${ }^{35} \mathrm{~S}$-methionine-labeled opsin band is indicated. Note the considerable amount of newly synthesized opsin generated by $r d s$ mice.
Instead, it appeared that opsin was synthesized at a constant rate at all times (Dudley et al., 1984). Therefore, in rodent retinas, diurnal variations in opsin gene expression at the transcriptional level may be damped at the translational level. Because the reported changes in opsin mRNA in the mouse retina are proportionally smaller in comparison to those reported in the toad and fish retina (Bowes et al., 1988; Korenbrot and Fernald, 1989), the procedures for detection of mRNA can apparently reveal small changes in mRNA that might not be apparent by the analysis of opsin synthesis. Triesman et al. (1988) described elevated opsin mRNA levels that peaked between P12 and P18. Accelerated disk assembly was observed in the developing mouse retina between P13 and P17, at which time the outer segment attained its adult length (LaVail, 1973). The circadian and developmental studies indicated a possible linkage between outer segment function, outer segment length, and maturation as signals for control of levels of opsin gene expression.

Because the $r d s$ retinal dystrophy generates a normal-appearing photoreceptor cell until the last stages of maturation (i.e., outer segment morphogenesis), we explored the effect of this mutation on opsin gene expression. Our results demonstrate that the mutant rod cells have nearly normal capacity for both opsin gene transcription and translation. Correction for cell loss was necessary to evaluate the reduction in mRNA level per retina. These corrections, based on morphometric analyses of cell loss, eliminated any major decrease in synthetic capacity (i.e., there were fewer cells synthesizing at nearly normal rates).

Earlier studies have shown that $r d s$ retinas had only $3 \%$ of the normal adult level of opsin (Schalken et al., 1985). Accumulation of opsin in the plasma membrane that envelops the inner segment, nucleus, and synaptic terminal accounts for some of the opsin detected (Nir and Papermaster, 1986; Jansen et al., 1987; Usukura and Bok, 1987). The affected rod cell clearly synthesizes and transports its photopigments to the plasma membrane but is unable to assemble it into stable disk membranes. The plasma membrane enclosing the residual photoreceptor in $r d s$ mutant mice is obviously limited in its capacity to store opsin. Therefore, opsin in the plasma membrane constitutes only a partial source of the low amount of opsin detected immunochemically. The bulk of the newly synthesized opsin is therefore released into the interphotoreceptor matrix as small vesicles or abortive disks that are destroyed by phagocytosis. 
Because opsin gene expression is not as seriously affected in the 11-30-d-old rds retinas, wc postulate that the low level of opsin $(3 \%)$ in this retina is a reflection of the absence of opsin sequestration in stable disk membranes. We cannot exclude accelerated turnover within the photoreceptor cell by autophagocytosis, but the stability of this low level suggests a low steady-state balance of nearly normal synthesis and destruction. The adult $r d s$ mouse rod, lacking an outer segment, resembles a normal immature photoreceptor at early slages of development (i.e., P7-8; Caravaggio and Bonting, 1963). At this age, the projecting cilium in the normal immature retina envelops a few disk membranes within its distal plasma membrane. In the $r d s$ photoreceptor, the ciliary tip is attached focally only to primordial disk membranes, but these fail to organize into normal disks. In the normal outer segment, newly synthesized disk membranes are enveloped by the plasma membrane and accumulate until hundreds of disks are stacked. These membranes survive until they move to the tip of the outer segment. Only after the disks are shed, engulfed, and ingested by the adjoining pigment epithelium is opsin destroyed. The turnover time of opsin in normal rods is determined not only by synthetic rates but also by the transit time between disk assembly at the base of the outer segment and disk shedding at the tip. In the mouse retina, the life span of a disk is about 10 days (LaVail, 1973). In the rds retina, newly synthesized opsin is packaged into vesicular membranes that are released to the subretinal space. These membranes are apparently available for engulfment and ingestion by the adjoining pigment epithelium shortly after being released into the subretinal space. Indeed, the immunocytochemical study revealed that opsin vesicles were phagocytosed as early as P7. It appears that as soon as the first opsin-laden vesicles are released to the subretinal space, phagocytosis ensues. In normal retinas, the onset of regulated phagocytosis is at P11 (LaVail, 1973). Therefore, in the $r d s$ mice, the removal of discarded opsin-containing membranes may not be subjected to the cycle of regulated phagocytosis that is imposed on normal outer segments by the prerequisite for circadian shedding. If the vesicular opsin-laden membranes are available for continuous clearance by the pigment epithelium, then the premature and continuous disposal of these vesicles accounts for the low amount of opsin observed in these mutant retinas.

In conclusion, despite the extremely low levels of opsin in the $r d s$ retinas, the levels of opsin mRNA and rates of opsin synthesis are not greatly reduced in comparison to the normal controls if the results are corrected for cell loss. Despite the absence of outer segments in the $r d s$ mouse retina, opsin gene transcription and translation are virtually unaffected by the $r d s$ mouse rod cell's failure to form a normal outer segment. These results, therefore, suggest that opsin might be considered a constitutive cell product that is continuously synthesized, albeit with circadian regulation, and inserted into vesicular membranes and into the photoreceptor cell's surface membranes. Whether or not ordered disk membranes are formed apparently does not affect opsin gene expression significantly. Despite this progress in describing opsin gene expression in these mutant mice and the recent isolation and sequencing of the mutated $r d s$ gene and identification of its normal counterpart as the protein peripherin, we are unable to explain why this defect should eventually cause cell death of rods.

\section{References}

Baehr W, Falk JD, Bugra K, Triantafyllos JT, McGinnis JF (1988) Isolation and analysis of the mouse opsin gene. FEBS Lett 238:253256.

Besharse JC (1986) Photosensitive membrane turnover: differentiated membrane domains and cell-cell interaction. In: The retina, a model for cell biological studies, Vol 1 (Adler R, Farber D, eds), pp 297352. New York: Academic.

Besharse JC, Hollyfield JG, Rayborn ME (1977) Photoreceptor outer segments: accelerated membrane renewal in rods after exposure to light. Science 196:536-538.

Bird AC, Flannery JG, Bok D (1988) A diurnal rhythm in opsin content of Rana pipiens rod inner segments. Invest Ophthalmol Vis Sci 29:1028-1039.

Bowes C, vanVeen T, Farber DB (1988) Opsin, G protein and 48$\mathrm{kDa}$ protein in normal and $r d$ mouse retinas: developmental expression of mRNAs and proteins and light/dark cycling of mRNAs. Exp Eye Res 47:369-390.

Caravaggio LL, Bonting SL (1963) The rhodopsin cycle in the developing vertebrate retina. II. Correlative study in normal mice and in mice with hereditary retinal degeneration. Exp Eye Res 2:12-19.

Chirgwin JM, Przybyla AE, MacDonald RJ, Rutter WJ (1979) Isolation of biologically active ribonucleic acid from sources enriched in ribonuclease. Biochemistry 18:5294-5299.

Cohen AI (1983) Some cytological and initial biochemical observations on photoreceptor in retinas of $r d s$ mice. Invest Ophthalmol Vis Sci 24:832-843.

Connell G, Bascom R, McInnes R, Molday RS (1990) Photoreceptor cell peripherin is the defective protein responsible for retinal degeneration slow $(r d s)$. Invest Ophthalmol Vis Sci Suppl 31:309.

Deretic D, Hamm HE (1987) Topographic analysis of antigenic determinants recognized by monoclonal antibodies to the photoreceptor guanyl nucleotide binding protein, transducin. J Biol Chem 262:1083910847 .

Dudley PA, Alligood JP, O'Brien PJ (1984) Biochemical events related to circadian photoreceptor shedding. In: Molecular and cellular basis of visual acuity (Hilfer SR, Sheffield JB, eds), pp 13-30. Berlin: Springer.

Hall MO, Bok D, Bachrach ADE (1969) Biosynthesis and assembly of the rod outer segment membrane system: formation and fate of visual pigment in the frog retina. J Mol Biol 45:397-406.

Hargrave PA, Adamus G, Arendt A, McDowell JH, Wang J, Szary A, Curtis D, Jackson RW (1986) Rhodopsin's amino terminus is a principal antigenic site. Exp Eye Res 42:363-373.

Jansen HG, Sanyal S, deGrip WJ, Schalken JJ (1987) Development and degeneration of retina in $r d s$ mutant mice: ultraimmunohistochemical localization of opsin. Exp Eye Res 44:347-361.

Korenbrot JI, Fernald RD (1989) Circadian rhythm and light regulate opsin mRNA in rod photoreceptors. Nature 337:454-457

LaVail MM (1973) Kinetics of rod outer segment renewal in the developing mouse retina. J Cell Biol 58:650-661.

LaVail MM, Battelle BA (1975) Influence of eye pigmentation and light deprivation on inherited retina dystrophy in the rat. Exp Eye Res 21:167-192.

Lehrach H, Diamond D, Wozney JM, Boedtker H (1977) RNA molecular weight determination by gel electrophoresis under denaturing condition, a critical reexamination. Biochemistry 16:4743-4751.

MacKenzie D, Arendt A, Hargrave P, McDowell JH, Molday RS (1984) Localization of binding sites for carboxyl terminal specific anti-rhodopsin monoclonal antibodies using synthetic peptides. Biochemistry 23:6544-6549.

Maniatis T, Fritsch EF, Sambrook J (1982) In: Molecular cloning: a laboratory manual. Cold Spring Harbor, NY: Cold Spring Harbor Laboratory.

Matsumoto B, Bok D (1984) Diurnal variations in amino acid incorporation into inner segment opsin. Invest Ophthalmol Vis Sci 25:1-9.

Nathans J, Hogness DS (1986) Isolation and nucleotide sequence of gene encoding human rhodopsin. Proc Natl Acad Sci USA 81:48514855 .

Nir I, Papermaster DS (1986) Immunocytochemical localization of 
opsin in the inner segment and ciliary plasma membrane of photoreceptor in retinas of $r d s$ mutant mice. Invest Ophthalmol Vis Res 27:836-840.

Nir I, Agarwal N, Sagie G, Papermaster DS (1989) Opsin distribution and synthesis in degenerating photoreceptors of $r d$ mutant mice. Exp Eye Res 49:403-421.

O'Niel RR, Mitchell LG, Merrill CR, Rasband WS (1989) Use of image analysis to quantitate changes in form of mitochondrial DNA after x-irradiation. Appl Theor Electrophor 1:163-167.

Papermaster DS, Schneider BG, Zorn MA, Kraehenbuhl JP (1978) Immunocytochemical localization of opsin in outer segments and Golgi zones of frog photoreceptors. J Cell Biol 77:196-210.

Papermaster DS, Schneider BG, Besharse JC (1985) Vesicular transport of newly synthesized opsin from the Golgi apparatus toward the rod outer segment: immunocytochemical and autoradiographic evidence. Invest Ophthalmol Vis Sci 26:1386-1404.

Reuter JH, Sanyal S (1984) Development and degeneration of retina in $r d s$ mutant mice: the electroretinogram. Neurosci Lett 48:231-237.

Sanyal S, Hawkins RK (1986) Development and degeneration of retina in $r d s$ mutant mice: effects of light on the rate of degeneration in albino and pigmented homozygous and heterozygous mutant and normal mice. Vision Res 26:1177-1185.

Schalken JJ, Janssen JM, deGrip WJ, Hawkins RK, Sanyal S (1985) Immunoassay of rod visual pigment (opsin) in the cycs of $r d s$ mutant mice lacking receptor outer segments. Biochim Biophy Acta 839:122126.
Schneider BG, Papermaster DS (1983) Immunocytochemistry of retina membrane protein biosynthesis at the electron microscopic level by the albumin embedding technique. Methods Enzymol 96:485-495.

St Jules RS, O'Brien PJ (1986) The acylation of rat rhodopsin in vitro and in vivo. Exp Eye Res 43:929-940.

Towbin H, Staehelin T, Gordon J (1979) Electrophoretic transfer of proteins from polyacrylamide gels to nitrocellulose sheets: procedure and some applications. Proc Natl Acad Sci USA 76:4350-4354.

Travis GH, Brennan MB, Danielson PE, Kozak CA, Sutcliffe JG (1989) Identification of a photoreceptor-specific $\mathrm{mRNA}$ encoded by the genc responsible for retinal degeneration slow $(r d s)$. Nature 338:70-73.

Treisman JE, Morabito MA, Barnstable CJ (1988) Opsin expression in the rat retina is developmentally regulated by transcriptional activation. Mol Cell Biol 8:1570-1579.

Usukura J, Bok D (1987) Changes in the localization and content of opsin during retinal development in the $r d s$ mutant mouse: immunocytochemistry and immunoassay. Exp Eye Res 45:501-515.

van Nie R, Ivanyi D, Demant $P$ (1978) A new H-2 linked mutation, $r d s$, causing retinal degeneration in the mouse. Tissue Antigens 12: 106-108.

Young RW (1967) The renewal of photoreceptor cell outer segments. J Cell Biol 33:61-72.

Young RW (1985) Cell differentiation in the retina of the mouse. Anat Rec 212:199-205. 